\title{
PENENTUAN BATAS WILAYAH DENGAN MENGGUNAKAN METODE KARTOMETRIK (Studi Kasus Daerah Kec. Gubeng Dan Kec. Tambaksari)
}

\author{
Pande Restu Adikresna P, Yanto Budisusanto \\ Program Studi Teknik Geomatika FTSP-ITS, Kampus ITS Sukolilo, Surabaya, 60111 \\ Email : yanto_b@geodesy.its.ac.id
}

\begin{abstract}
Abstrak
Penentuan batas wilayah adalah penentuan garis batas antara dua daerah atau lebih dimana garis batas tersebut disepakati oleh pihak dari daerah tersebut. Batas wilayah merupakan hal yang penting karena merupakan salah satu faktor untuk menunjang perkembangan dari suatu daerah. Terdapat berbagai macam metode untuk menentukan garis batas. Salah satunya dengan menggunakan metode kartometrik.
\end{abstract}

Metode kartometrik merupakan metode penelusuran garis batas wilayah dengan menentukan posisi titik-titik koordinat dan mengidentifikasi cakupan wilayah pada peta kerja atau citra yang telah terkoreksi. Pentuan batas wilayah menggunakan metode kartometrik ini ditampilkan dengan sistem informasi peta batas wilayah antara kedua kecamatan tersebut. Terdapat 427 titik kartometrik yang tersebar di Kecamatan Gubeng dan Tambaksari dengan penomeran sesuai dengan format yang ditentukan.

Dari kegiatan penelitian ini ditemukannya 10 panjang segmen batas yang berbeda pada peta digital yang di ambil dari Peta RBI dengan hasil segmen batas yang didapat dari hasil verivikasi sepanjang 1748.968 Meter . Terdapat 2 jenis segmen unsur batas yaitu segmen batas alam berupa sungai dengan panjang 8225.82 meter dan segmen batas buatan berupa jalan, tembok dan selokan sepanjang 41805.743 Meter. Status batas wilayah yang terdapat di kedua kecamatan setelah dilalukan verifikasi dibagi menjadi 2 jenis yaitu batas disepakati sepanjang 48850.357 Meter, batas tidak diketahui sepanjang 1207.851 Meter. Titik kartometrik merupakan cara yang efektif untuk mewakili garis batas wilayah. Hasil dari penentuan batas ini disajikan melalui sistem informasi batas wilayah Kec. Gubeng dan Tambaksari.

Kata kunci: Segmen batas, Titik Kartometrik, Sistem informasi batas wilayah,

\section{PENDAHULUAN}

Penegasan batas wilayah semakin terasa penting di era pelaksanaan otonomi daerah. Setiap daerah berupaya menggali potensi ekonomi daerahnya untuk meningkatkan kesejahteraan masyarakat. Penegasan batas daerah secara pasti ditetapkan oleh Kementrian Dalam Negeri dengan berpedoman pada Undang-undang Pembentukan Daerah (2012). Batas daerah yang tidak memiliki kepastian secara hukum dapat memicu terjadinya konflik antara dua atau lebih daerah yang berbatasan.

Konflik permasalahan batas yang terjadi biasanya bersumber pada pemberian izin kegiatan, pembagian hasil pengelolaan kegiatan di suatu wilayah, maupun akibat dari interaksi antara masyarakat disekitar lokasi kegiatan ekonomi. Disamping itu permasalahan batas daerah muncul antara lain disebabkan oleh pemekaran Daerah Otonom Baru, perebutan sumber daya alam terkait dengan pendapatan asli daerah dan kurangnya pemahaman terhadap garis batas pada peta dasar yang ada.

Oleh karena itu penegasan batas daerah sangat penting untuk mencegah terjadinya konflik batas daerah yang dapat menimbulkan kerugian materi atau non materi. Bila tidak segera diselesaikan maka berpotensi menurunkan tingkat pelayanan kepada masyarakat, contohnya seperti pertikaian masalah batas wilayah di NTT terjadi di sejumlah wilayah, seperti di perbatasan Desa Lohayong dan Wulublolong memicu bentrokan yang menyebabkan tiga orang tewas dan ratusan rumah dibakar.

Untuk meminimalisir terjadinya konflik dalam suatu masalah penentuan batas daerah 
diperlukan pembuatan peta batas daerah berdasarkan perundang-undangan yang berlaku. Pada penelitian ini akan di buat peta batas wilayah dengan menggunakan metode kartometrik. Metode kartometrik adalah penelusuran/penarikan garis batas pada peta kerja dan pengukuran/penghitungan posisi titik, jarak serta luas cakupan wilayah dengan menggunakan peta dasar dan peta-peta lain sebagai pelengkap (Kemendagri, 2012). Metode ini merupakan salah satu metode alternatif yang terdapat dalam Peraturan Menteri Dalam Negeri no 76 tahun 2012 tentang pedoman penentuan batas daerah. Pembuatan peta batas wilayah ini diharapkan dapat bermanfaat untuk menghindari masalah konflik batas dan dapat juga mengoptimalkan pengelolaan daerah tersebut.

\section{METODOLOGI PENELITIAN}

\section{A. Lokasi penelitian}

Lokasi penelitian ini mengambil studi kasus di Kecamatan Gubeng yang terbagi menjadi 6 kelurahan dan Kecamatan Tambaksari yang dibagi menjadi 8 kelurahan (Lihat gambar 1). Letak geografis dari lokasi penelitian ini adalah:
Batas utara : Kecamatan Kenjeran
Batas timur : Kecamatan Sukolilo
Batas selatan : Kecamatan Wonokromo
Batas barat : Kecamatan Tegal Sari, Genteng

B. Data dan Peralatan

Data yang dibutuhkan meliputi:

- Peta RBI Kota Surabaya

- Citra worldview

- Peta topografi

- Peta Pajak Bumi dan Bangunan (PBB)

Peralatan yang digunakan dalam penelitian ini adalah:

Perangkat Keras (Hardware)

- Laptop Intel core i3

- Memori 2 GB

- Display ATI Radeon HD 3200 Grapics

- Hard disk 250 GB

Perangkat Lunak (Software)

- Microsoft Office 2007. Perangkat lunak ini digunakan dalam penulisan laporan, rekapitulasi data (luas, persentase persebaran, potensi), , pembuatan diagram, grafik, dan slide presentasi.
- Perangkat lunak pengolah data citra.

- ArcGIS 10 digunakan untuk penampalan dan penentuan garis batas wilayah. Perangkat lunak ini juga digunakan untuk pembuatan atribut peta.

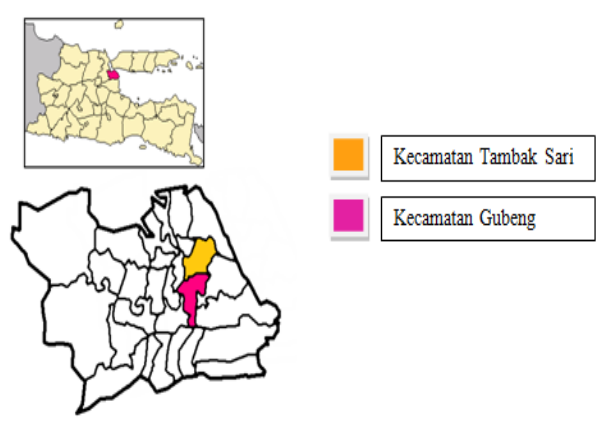

Gambar. 1. Lokasi penelitian

C. Metode Penelitian

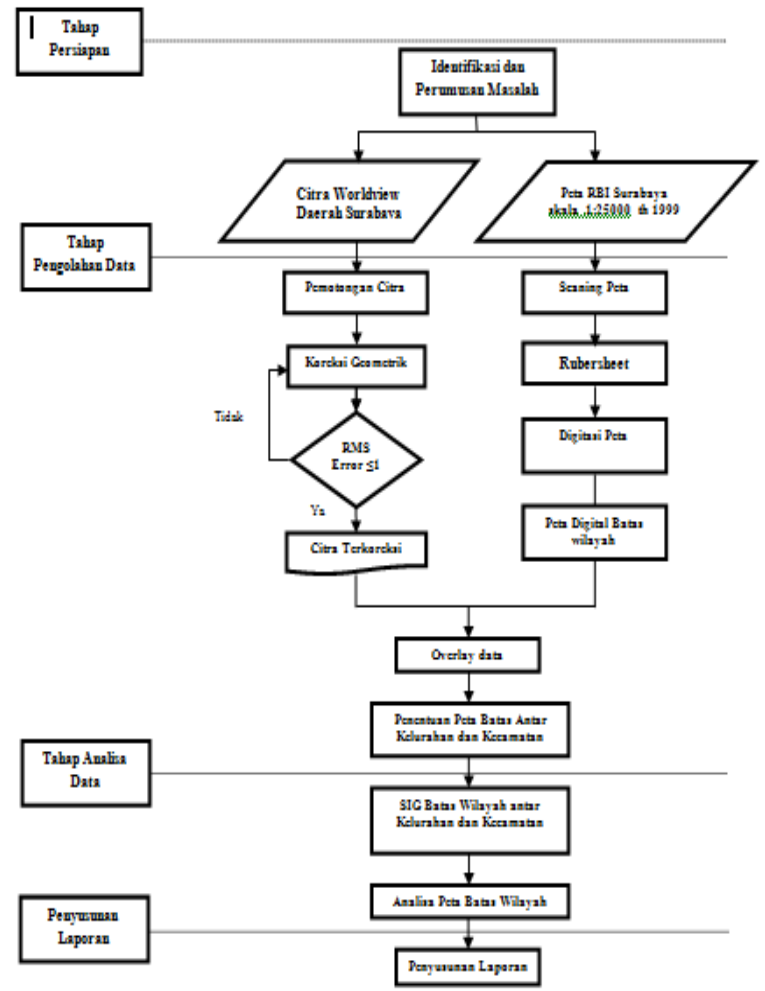

Gambar. 2. Diagram Alir Penelitian

Tahapan penelitian ini dijelaskan pada gambar 2 . Identifikasi Masalah dalam penelitian ini adalah bagaimana pembuatan peta batas daerah kecamatan dan kelurahan. Menetukan batas wilayah antara keluarahan dan kecamatan yang berdampingan. Pengumpulan data berupa data Peta RBI tahun 1999 daerah Kota Surabaya dan citra worldview tahun 2012 yang meliputi wilayah Kota Surabaya. 
Penelitian ini menggunakan metode kartometrik untuk menentukan batas wilayah tiap kelurahan di Kecamatan Gubeng dan Tambaksari dimana metode ini didukung dengan penggunaan pemetaan partisipatif. Pemetaan Partisipatif adalah pemetaan yang dilakukan oleh kelompok masyarakat mengenai tempat atau wilayah di mana mereka hidup. pemetaan partisipatif dilakukan oleh masyarakat setempat dikarena masyarakat yang hidup dan bekerja di tempat itulah yang memiliki informasi pengetahuan mendalam mengenai garis batas wilayah[3]. Pemetaan partisipatif (partisipatory mapping) menjadi salah satu unsur dalam pembangunan infrastruktur informasi geospasial.Sinergi yang baik dan saling mendukung dari semua unsur masyarakat dapat mempercepat proses dalam pemetaan batas wilayah serta meminimalisir terjadinya konflik di lapangan pada saat penentuan garis batas wilayah.

Dari kegiatan tersebut dihasilkan peta batas wilayah antar kelurahan di dua kecamatan yang disajikan berupa sistem informasi batas wilayah.

\section{HASIL DAN PEMBAHASAN}

\section{A. Hasil Penentuan Batas Wilayah}

Pada bagian ini ditampilkan hasil pelaksanaan penelitian yang telah dilakukan mengenai penetuan batas wilayah menggunakan metode kartometrik.

Pelaksanaan penelitian ini difokuskan pada penentuan garis batas kelurahan di dua Kecamatan Gubeng dan Tambaksari. Kegiatan penelitian penentuan batas wilayah dengan metode kartometrik ini menghasilkan sistem informasi mengenai batas wilayah tentang :

- Panjang segmen batas

Berdasarkan dari data verifikasi batas wilayah yanag dilakukan di Kecamatan Gubeng dan Tambaksari didapat perbedaan panjang segmen batas yang di tampilkan pada table 1 dibawah ini.
Tabel 1. panjang segmen batas

\begin{tabular}{llll}
\hline No & $\begin{array}{l}\text { Panjang } \\
\text { Segmen } \\
\text { Batas RBI }\end{array}$ & $\begin{array}{l}\text { Panjang } \\
\text { Segmen Batas } \\
\text { Verivikasi }\end{array}$ & $\begin{array}{l}\text { Perbedaan } \\
\text { Panjang } \\
\text { Segmen } \\
\text { Batas }\end{array}$ \\
\hline \multirow{2}{*}{1} & $\begin{array}{l}48309.240 \\
\text { Meter }\end{array}$ & $\begin{array}{l}50058.208 M e t \\
\text { er }\end{array}$ & $\begin{array}{l}2702,037 \\
\text { Meter }\end{array}$ \\
\hline
\end{tabular}

- Panjang batas alam dan batas buatan.

Segmen batas di Kecamatan Gubeng dan Tambaksari berdasarkan unsur batas wilayah yang dilalui dibagi menjadi dua unsur yaitu batas alam dan buatan. batas alam meliputi sungai, dan batas buatan berupa jalan, rel kereta, dan saluran irigasi. Pada tabel 2 dijelaskan mengenai panjang unsur batas yang terdapat di kedua kecamatan tersebut.

Tabel 2. panjang segmen batas

\begin{tabular}{ll}
\hline Batas Alam & Batas Buatan \\
\hline 8225.82 meter & 41805.743 Meter \\
\hline
\end{tabular}

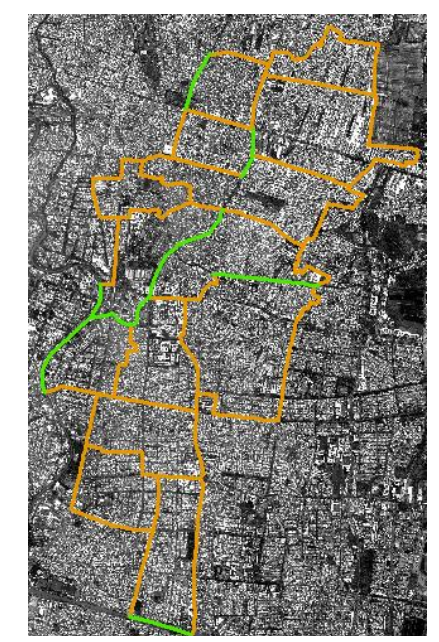

Gambar 3. Batas Alam dan Buatan

Dari gambar 3 garis yang berwarna orange merupakan garis batas buatan sedangkan garis berwarna hijau merupakan batas alam.

- Status batas wilayah

Panjang segmen batas kelurahan di dua kecamatan dibagi menjadi tiga jenis yang ditampilkan pada table berikut. 
Tabel 3. Status Segmen Batas

\begin{tabular}{l|l|l}
\hline $\begin{array}{l}\text { Batas } \\
\text { Diesepakati }\end{array}$ & $\begin{array}{l}\text { Batas } \\
\text { Sengketa }\end{array}$ & $\begin{array}{l}\text { Batas Belum } \\
\text { Diketahui }\end{array}$ \\
\hline $\begin{array}{l}48850.357 \\
\text { Meter }\end{array}$ & & $\begin{array}{l}1207.851 \\
\text { Meter }\end{array}$ \\
\hline
\end{tabular}

- Titik kartometrik batas wilayah

Titik kartometrik yang terdapat pada kedua kecamatan berjumlah 427 titik yang tersebar di setiap garis segmen batas untuk mewakili batas dari masing-masing wilayah yang berisi informasi koordinat dari lokasi titik dan daerah yang bersinggungan dengan titik kartometrik.

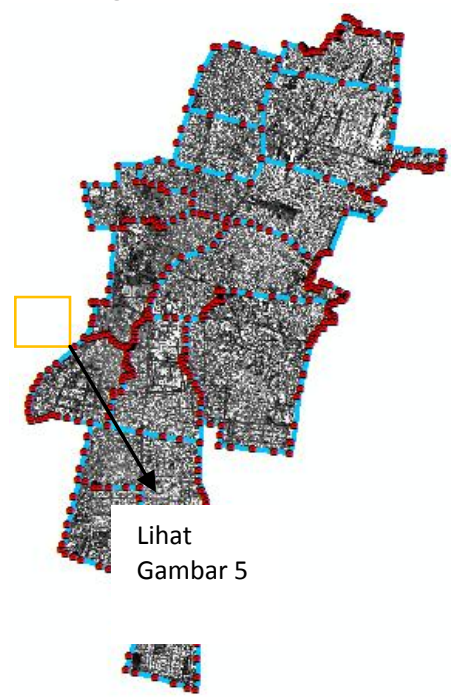

Gambar 4. Sebaran Titik Kartometrik

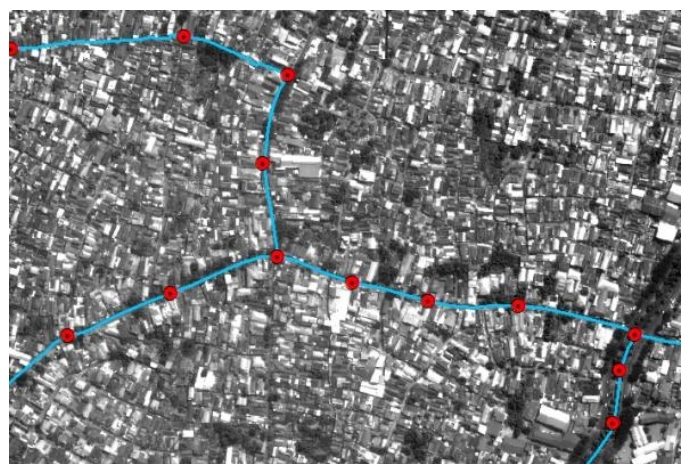

Gambar 5. Titik Kartometrik

Gambar 4 dan Gambar 5 menjukan titik kartometrik yang tersebar di Kecamatan Gubeng dan Tambaksari. Titik berwarna merah menunjukan letak titik kartometrik di dua Kecamatan Gubeng dan Tambaksari.

B. Analisa Penentuan Batas Wilayah

- Analisa Panjang Segmen Batas
Dalam penelitian mengenai batas penentuan batas wilayah menguunakan metode kartometrik ini batas wilayah yang di ambil dari peta RBI tahun 1999 di Kecamatan Gubeng dan Tambaksari. Dari hasil verifikasi penentuan batas wilayah menggunakan metode kartometrik ini ditemukan garis segmen batas wilayah yang berbeda sepanjang 1748.968 Meter. Ditemukan 10 semen batas yang berbeda yang ditunjukan pada gambar 6 dibawah ini.

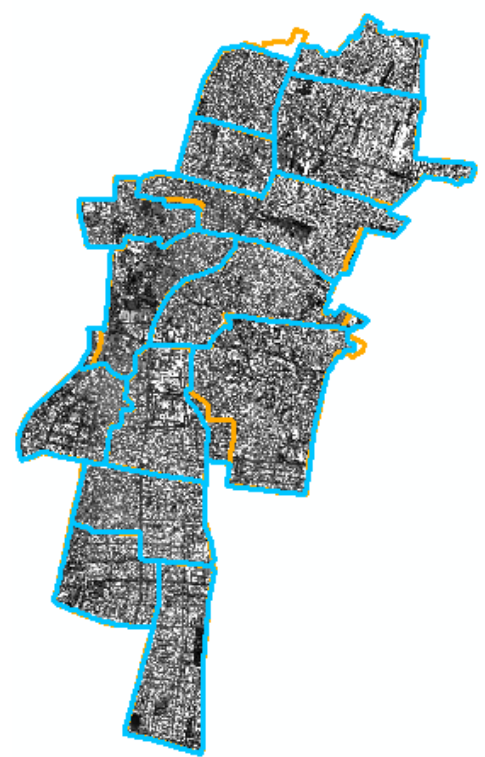

Gambar 6. Segmen Batas Yang Berbeda

Segmen batas yang berbeda terletak antara:

- Kelurahan Airlangga dan Mojo.

- Kelurahan Mojo dan Pacarkembang.

- Kelurahan Gubeng.

- Kelurahan Ploso dan Tambaksari.

- Kelurahan Ploso dan Gading.

- Kelurahan Ploso.

- Kelurahan Gading dan Kapasan Madya Baru.

- Kelurahan Gading dan Dukuh Setro.

- Kelurahan Dukuh Setro dan Kapasan Madya Baru.

- Kelurahan Dukuh Setro.

- Analisa Status Batas wilayah

Total panjang batas yang terletak di Kecamatan Gubeng dan Tambaksari adalah Meter dimana 1207.851 Meters merupakan batas yang belum diketahui. Segmen batas yang berstatus belum diketahui ini terletak diantara Kelurahan Ploso dan Tambaksari (lihat gambar 7 dan gambar 8). Karena dari pihak Kelurahan Tambaksari yang 
belum memberikan kejelasan mengenai lokasi batasnya.

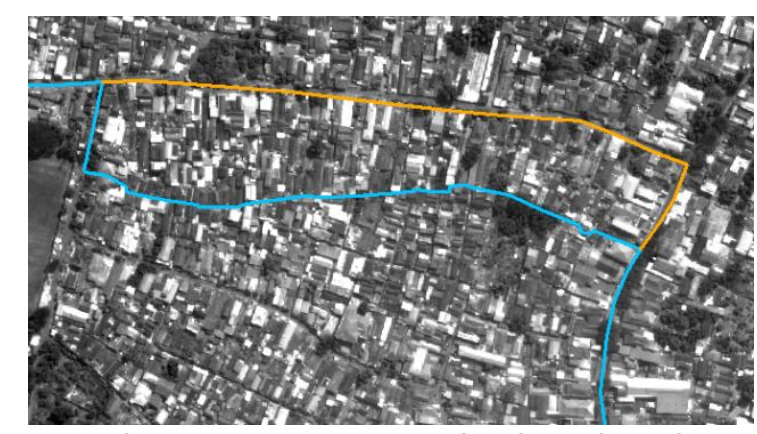

Gambar 7. Segmen Batas Kelurahan Ploso dan Tambaksari
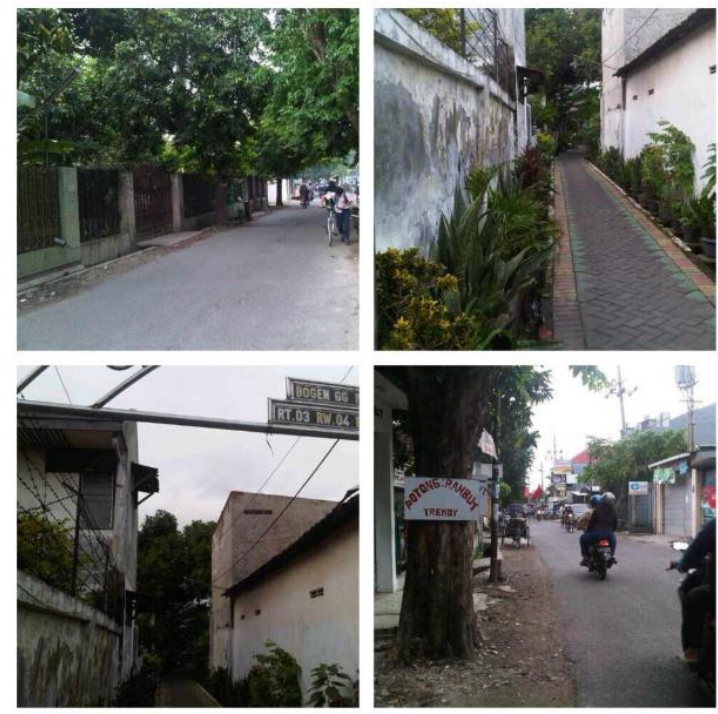

Gambar 8. Segmen Batas Kelurahan Ploso dan Tambaksari

Untuk segmen batas lain nya tidak mengalami suatu permasalahan karena dari setiap kelurahan yang berdampingan menyepakati dan tidak mempermasalahkan garis batas yang telah ditentukan.

- Analisa Titik Kartometrik

Titik kartometrik ditempatkan di sepanjang segmen batas wilayah yang ada.titik tersebut berisikan informasi mengenai kordinat letak titik dan nama kelurahan yang bersinggungan dengan titik kartometrik tersebut. Penentuan titik kartometik ini dirasa sangat efisien, dimana titik tersebut dapat mewakili secara utuh setiap titik belok pada garis batas wilah tanpa dipengaruhi Terdapat 427 titik kartometrik yang tersebar di Kecamatan Gubeng dan Tambaksari dengan penomeran sesuai dengan format yang ditentukan. Tabel 4 merupakan table kode wilayah penomeran titik kartometrik di kedua wilayah kecamatan ini:

Tabel 4. Kode wilayah

\begin{tabular}{ll}
\hline No & Wilayah \\
\hline \hline 35 & Povinsi Jawa Timur \\
78 & Kota Surabaya \\
100 & Kecamatan Gubeng \\
01 & KelurahanBarata Jaya \\
02 & Kelurahan Pucang sewu \\
03 & Kelurahan Kertajaya \\
04 & Kelurahan Gubeng \\
05 & Kelurahan Airlangga \\
06 & Kelurahan Mojo \\
200 & Kecamatan Tambaksari \\
01 & Kelurahan Pacar Keling \\
02 & Kelurahan Pacar Kembang \\
03 & Kelurahan Ploso \\
04 & Kelurahan Tambaksari \\
05 & Kelurahan Rangkah \\
06 & Kelurahan Gading \\
07 & Kelurahan Kapasan Madya Baru \\
08 & Kelurahan Dukuh setro \\
\hline &
\end{tabular}

Format penomeran titik di urut dari kode provinsi ke kode kelurahan dan dua digit terakhit merupakan nomer titik kartometrik seperti contoh berikut ini.

\section{- $\quad 35.78 .001 .01 .02 .01$}

Sistem penomeran tersebut merupakan titik kartometrik yang berhimpitan dengan dua kelurahan di kecamatan yang sama.

- $\quad 35.78 .001 .01 .02 .03 .01$

Apabila titik ini merupakan titik temu dari tiga garis batas wilayah yang berbeda di kecamatan yang sama.

- $\quad 35.78 .001 .002 .01 .02 .01$

Format penomeran titik ini menunjukan bahwa titik kartometrik mewakili batas antara dua kelurahan sekaligus juga mewakili batas kecamatan.

\section{- $\quad 35.78 .001 .002 .01 .02 .0 .3 .01$}

Penomeran titik seperti ini menunjukan titik tersebut merupakan titik batas antara tiga kelurahan dan mewakili batas antara dua kecamatan yang saling bertetangga. 
Data didapat dari hasil verifikasi batas dengan menggunakan metode kartometrik dengan didukung peta yang dimiliki tiap kelurahan. Berikut merupakan dokumentasi dari kegiatan verifikasi batas yang dilakukan.

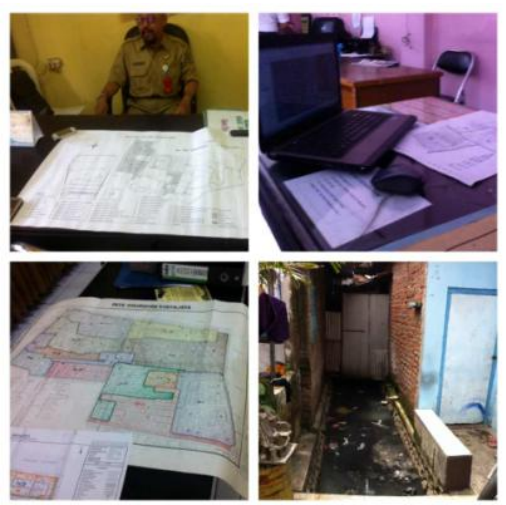

Gambar 9. Dokumentasi Verifikasi Segmen Batas

\section{KESIMPULAN DAN SARAN}

Dari penelitian diatas dapat disimpulkan bahwa:

1. Ditemukannya 10 panjang segmen batas yang berbeda pada peta digital yang di ambil dari Peta RBI dengan hasil segmen batas yang didapat dari hasil verivikasi sepanjang 1748.968 Meter. Perbedaan panjang tersebut dipengaruhi oleh adanya pemekaran wilayah di Kelurahan Gading yang di bagi menjadi tiga wilayah kelurahan.

2. Terdapat 2 jenis segmen unsur batas yang terdapat di kecamatan tersebut yaitu segmen batas alam berupa sungai dengan panjang 8225.82 meter dan segmen batas buatan berupa jalan tembok dan selokan sepanjang 41805.743 Meter.

3. Status batas wilayah yang terdapat di kedua kecamatan setelah dilalukan survey dibagi menjadi 2 jenis yaitu batas disepakati sepanjang 48850.357 Meter dan batas tidak diketahui sepanjang 1207.851 Meter.

4. Titik kartometrik merupakan cara efektif untuk mewakili garis segmen batas wilayah dengan tepat di setiap titik belok dan dapat diletakan di lokasi yang tidak dimungkinkan untuk dilakukan nya pemasangan patok batas di lapangan.

\section{DAFTAR PUSTAKA}

Kementrian Dalam Negeri, (2012), Peraturan Menteri Dalam Negeri Republik Indonesia Nomor 76 Tahun 2012 Tentang Pedoman Penegasan Batas Daerah, Jakarta.

Kementrian Dalam Negeri, (2012), Lampiran Peraturan Menteri Dalam Negeri Republik Indonesia Nomor: 76 Tahun 2012 Tentang Pedoman Penegasan Batas Daerah Jakarta.

Daud (2013), Pemetaan Partisipatif $<$ www.academia.edu/3647639/Pemetaan_ partisipatif > 4-01-2014 Jam 16.47 PM 